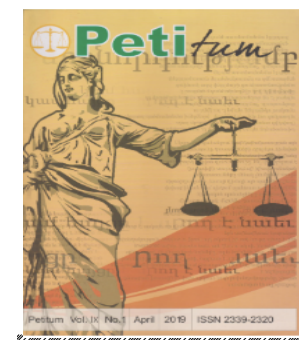

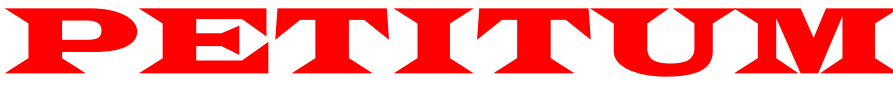 \\ https://uit.e-journal.id/JPetitum \\ Vol 8, No, 2, Oktober 2020 pp, 131-142 \\ p-ISSN:2339-2320 dan e-ISSN: 2716-0o17
}

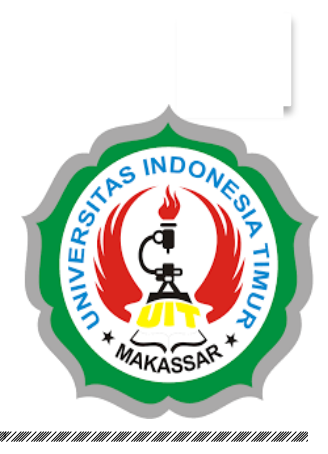

\section{Implementasi Asas Sederhana Pendaftaran Tanah Sistematis Lengkap dalam Menjamin Hak Keperdataan}

\author{
Aisyah $^{1}$, Haris Retno Susmiyati ${ }^{2}$, \& Rahmawati Al-Hidayah ${ }^{3}$ \\ 1Fakultas Hukum, Universtas Mulawarman, Email: aisharizki28@gmail.com \\ 2Fakultas Hukum, Universitas Mulawarman, Email: harisretno@fh.unmul.ac.id \\ ${ }^{3}$ Fakultas Hukum, Universitas Mulawarman, Email: rahmawatialhidayah@gmail.com
}

\begin{abstract}
Artikel info
Artikel history:

Received; 17-10-2020

Revised: 20-10-2020

Published: 22-10-2020

\section{Keywords:}

Simple Priciple;

Complete Systematic

Land Registration; Civil

Rights.

ABSTRACT: This study aim to analyze the implementation of the simple principle of Complete Systematic Land Registration in guaranteeing civil rights. This research uses the socio-legal research method which is a research approach that is carried out directly from the community as the first source through field research from the relevant institute. Based on the research conducted, it can be concluded that the implementation of the simple principle at the research location has not run optimally because the legal language and technical language in the land registration procedure are difficult to understand by the community, so that it implies that a simple principle has not been created in the Systematic Complete Land Registration. Simple principles in regulations need to be concretized in technical regulations to interpret these simple principles so that there are no more obstacles in land registration procedures so as to guarantee legal certainty and ease in land registration.
\end{abstract}

\section{Kata Kunci:}

Asas Sederhana;

Pendaftaran Tanah

Sistematis Lengkap;

Hak Keperdataan.
ABSTRAK: Penelitian ini bertujuan untuk tentang implementasi asas sederhana Pendaftaran Tanah Sistematis Lengkap dalam menjamin hak keperdataan. Penelitian ini menggunakan metode socio-legal research yaitu pendekatan penelitian yang dilakukan langsung dari masyarakat sebagai sumber pertama melalui penelitian lapangan dari instansi terkait. Berdasarkan penelitian yang dilakukan, dapat disimpulkan bahwa implementasi asas sederhana di lokasi penelitian belum berjalan secara optimal karena bahasa hukum dan bahasa teknis dalam prosedur pendaftaran tanah sulit dipahami oleh masyarakat, sehingga berimplikasi belum terciptanya asas sederhana dalam Pendaftaran Tanah Sistematis Lengkap. Asas sederhana dalam peraturan perlu dikonkretkan regulasi teknisnya untuk menafsirkan asas sederhana tersebut agar tidak terjadi lagi hambatan dalam prosedur pendaftaran tanah sehingga menjamin kepastian hukum serta kemudahan dalam pendaftaran tanah.

Coresponden author:

Email: aisharizki28@gmail.com artikel dengan akses terbuka dibawah lisensi CC BY 


\section{PENDAHULAN}

Undang-Undang Dasar Negara Republik Indonesia Tahun 1945 menegaskan bahwa Negara Indonesia merupakan Negara yang berdasarkan atas hukum dan tidak berdasarkan atas kekuasaan belaka. Demikian pula soal tanah, pemerintah berkewajiban memberikan kepastian hukum terhadap status tanah yang dikuasai masyarakat atau badan usaha. Undang-Undang Nomor 5 Tahun 1960 tentang Peraturan Dasar Pokok-Pokok Agraria menyatakan untuk menjamin kepastian hukum, diadakan pendaftaran tanah di seluruh wilayah Republik Indonesia dan bahwa sertipikat hak atas tanah merupakan bukti yang kuat mengenai suatu penguasaan atau kepemilikan tanah. Jaminan kepastian hukum yang hendak diwujudkan dalam pendaftaran tanah ini meliputi kepastian status hak yang didaftar, subjek hak, dan objek hak. Oleh karena itu perlu dilakukan percepatan pendaftaran tanah untuk mengejar presentase tanah terdaftar (Sumardjono, 2005).

Pemerintah melalui Kementerian Agraria dan Tata Ruang/Kepala Badan Pertanahan Nasional yang mempunyai kewenangan melakukan pendaftaran tanah telah berupaya untuk percepatan pendaftaran tanah. Program/proyek yang telah ada sebelumnya melalui Program Nasional Agraria (Prona) ditahun 1981, Proyek Administrasi Pertanahan (PAP) yang dimulai sejak tahun 1994 sampai tahun 2000, Layanan Rakyat Sertipikasi Tanah (Larasita) dan Sertipikasi Massal Swadaya pada tahun 2006 sampai tahun 2009 serta Land Management and Policy Development Project (LMPDP) pada tahun 2009 belum dapat mencapai target pendaftaran tanah di seluruh Indonesia yakni 126 juta bidang tanah karena merujuk pada hasil pendaftaran tanah yang sudah terdaftar selama ini kurang dari 50 persen (Wahyono, 2017). Padahal sudah 59 tahun yang lalu perintah berkewajiban untuk mendaftarkan tanah sebagaimana yang telah di amanatkan oleh Undang-Undang Pokok Agraria (Ikhsan, 2019).

Program saat ini adalah Pendaftaran Tanah Sistematis Lengkap (PTSL) yang diatur dalam Peraturan Menteri Agraria dan Tata Ruang/Kepala Badan Pertanahan Nasional Nomor 12 Tahun 2017 sebagaimana diubah dengan Peraturan Menteri Agraria dan Tata Ruang/Kepala Badan Pertanahan Nasional Nomor 6 Tahun 2018 tentang Pendaftaran Tanah Sistematis Lengkap. Program-program pendaftaran tanah sebelumnya dilaksanakan dalam tataran kementerian, bukan dalam puncak pemerintahan yang tertinggi yaitu Presiden. Inilah yang membedakan Program Pendaftaran Tanah Sistematis Lengkap dengan program-program sebelumnya, sebagaimana telah dikeluarkan Instruksi Presiden Nomor 2 Tahun 2018 Tentang Percepatan Pendaftaran Tanah Sistematis Lengkap. Presiden memantau, mengevaluasi bahkan turun tangan langsung dalam pembagian sertipikat (Mujiburohman, 2018). Program sertipikasi ini dimaksudkan agar seluruh masyarakat dapat memiliki sertipikat hak atas tanah yang berlandaskan asas sederhana, aman, terjangkau, mutakhir dan terbuka, yang tertuang dalam Peraturan Pemerintah Republik Indonesia Nomor 24 Tahun 1997 tentang Pendaftaran Tanah. Asas sederhana bermakna agar ketentuan-ketentuan pokoknya maupun prosedurnya dengan mudah dapat dipahami oleh pihak-pihak yang berkepentingan serta jelas haknya bagi pemegang hak atas tanah (Sembiring Joses, 2010).

Secara konseptual, asas sederhana telah muncul di Peraturan Pemerintah Nomor 24 Tahun 1997 Tentang Pendaftaran Tanah. Namun permasalahan tanah masih di 
seputar prosedurnya yang rumit, sehingga masih perlu dikaji bagaimana arti asas sederhana. Meskipun regulasi sebagai payung hukum Pendaftaran Tanah Sistematis Lengkap telah diterbitkan dan kerjasama atau koordinasi antar instasi telah dibangun, namun dalam tataran implementasi masih terdapat hambatan dalam penerbitan sertipikat. Salah satu persoalan terkait pelaksanaan Pendaftaran Tanah Sistematis Lengkap dijKota Samarinda adalah alasan berubahnya data fisik dengan data yuridis setelah dilakukannya pengukuran membuat masyarakat tidak mau mensertipikatkan tanahnya. Sekitar 100 pengukuran data fisik berbeda dengan data yuridis milik pendaftar dan hampir 200 pendaftar yang protes karena masih adanya biaya yang harus dikeluarkan (Ikhsan, 2019). Hal ini menunjukan bahwa penerapan asas sederhana berimplikasi pada ketidaktepatan pada data fisik dan data yuridis serta pengaturan biaya penerbitan sertipikat yang mempengaruhi hak keperdataan pemegang hak atas tanah (objek hukum yang dimiliki oleh subjek hukum yang melakukan pendaftaran tanah). Oleh karena itu, dalam penelitian ini akan timbul dua pertanyaan diantaranya: 1) Bagaimana asas sederhana dalam sistem pendaftaran tanah di Indonesia? 2) Bagaimana implementasi asas sederhana dalam program Pendaftaran Tanah Sistematis Lengkap dalam menjamin hak keperdataan?

\section{METODE PENELITIAN}

Dalam penelitian ini, menggunakan pendekatan socio-legal research, yaitu pendekatan penelitian yang dilakukan langsung dari masyarakat sebagai sumber pertama dengan melalui penelitian lapangan. Pendekatan pada socio-legal research diperlukan untuk menjawab masalah-masalah sosial, bekerja atau tidak bekerjanya hukum, menguji efektifitas, serta kegunaan peran kewenangan, serta upaya-upaya pembaruan hukum yang dimungkinkan dilakukan (Waluyo, 2002). Pendekatan socio-legal research memberikan upaya terhadap gap atau jurang terpisah antara idealitas norma dengan realitas social (Marzuki \& Peter, 2006).

Pilihan pendekatan pada socio-legal research tidak berarti mengesampingkan dukungan dari sisi doctrinal karena salah satu sasaran studi ini melihat seperangkat norma positif dalam kaitannya dengan implementasi Asas Sederhana Pendaftaran Tanah Sistematis Lengkap, termasuk dukungan sisi teori hukum dengan tujuan untuk verifikasi pelaksanaan hukum dalam praktek (pembentukan dan penerapan).

\section{HASIL DAN PEMBAHASAN}

\section{A. Asas Sederhana Dalam Sistem Pendaftaran Tanah Di Indonesia}

Dalam melaksanakan prosedur pendaftaran tanah berpedoman dengan asas-asas. Secara konseptual, asas sederhana telah muncul di Peraturan Pemerintah Nomor 24 Tahun 1997 tentang Pendaftaran Tanah. Namun permasalahan tanah masih di seputar prosedurnya yang rumit, sehingga masih perlu dikaji bagaimana arti asas sederhana. Pasal 2 Peraturan Pemerintah Republik Indonesia Nomor 24 Tahun 1997 tentang Pendaftaran Tanah berbunyi "Pendaftaran tanah dilaksanakan berdasarkan asas sederhana, aman, terjangkau, mutakhir dan terbuka".

Asas sederhana tersebut diartikan sebagai asas yang mengatur agar ketentuanketentuan pokok dalam pendaftaran tanah maupun prosedurnya mudah dipahami 
oleh pihak-pihak yang berkepentingan, terutama para pemegang hak atas tanah. Prosedur pengumpulan data penguasaan tanah dipertegas, dipersingkat dan disederhanakan.

Asas sederhana dalam penjelasan Peraturan Pemerintah Nomor 24 Tahun 1997 tentang Pendaftaran Tanah tersebut mengandung beberapa unsur yaitu:

\section{Diagram 1.1 Unsur-Unsur Asas Sederhana dalam PP Nomor 24 Tahun 1997}

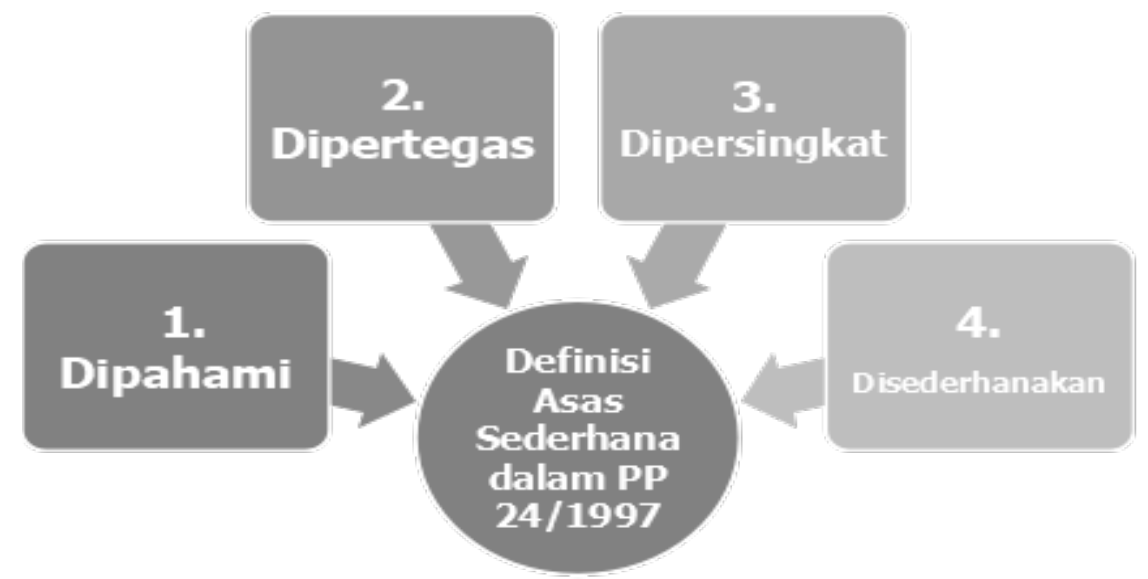

Sumber : Penjelasan umum dan Pasal 2 PP Nomor 24 Tahun 1997 tentang Pendaftaran Tanah

Unsur-unsur asas sederhana dalam Peraturan Pemerintah Nomor 24 Tahun 1997 terdiri atas 4 unsur yaitu mudah dipahami, dipertegas, dipersingkat dan disederhanakan.

Pertama unsur dipahami, definisi dipahami menurut KBBI adalah turunan dari kata paham yang artinya mengerti benar, tahu benar. Artinya ketentuan-ketentuan pokok maupun prosedur pendaftaran tanah harus mudah dimengerti dan pihak yang berkepentingan tahu benar bagaimana ketentuan-ketentuan dan peraturanperaturan dalam pendaftaran tanah. Unsur kedua dipertegas, definisi dipertegas menurut KBBI adalah turunan dari kata tegas yang artinya jelas dan terang benar. Artinya prosedur pengumpulan data penguasaan tanah harus jelas guna menjamin kepastian hukum di bidang penguasaan tanah dan kepemilikan tanah.

Unsur ketiga dipersingkat, definisi dipersingkat menurut KBBI adalah turunan dari kata singkat yang artinya pendek dan ringkas. Artinya prosedur pengumpulan data penguasaan tanah harus ringkas dalam segi waktu guna menjamin kemudahan dalam mendapat hak di bidang penguasaan tanah dan kepemilikan tanah. Unsur keempat disedeharnakan, definisi disederhanakan menurut KBBI adalah turunan dari kata sederhana yang artinya tidak berlebih-lebihan dan tidak banyak selukbeluknya/kesulitan. Artinya prosedur pengumpulan data penguasaan tanah disederhanakan seharusnya tidak diberikan kesulitan guna menjamin kemudahan dalam mendapat hak di bidang penguasaan tanah dan kepemilikan tanah.

Pengertian pendaftaran tanah dan asas sederhana dalam Peraturan Menteri Agraria dan Tata Ruang/Kepala Badan Pertanahan Nasional Nomor 6 Tahun 2018 tentang Pendaftaran Tanah Sistematis Lengkap sama dengan pengertian pendaftaran tanah 
dalam Peraturan Pemerintah Nomor 24 Tahun 1997 tentang Pendaftaran tanah karena peraturan menteri ini mengacu pada peraturan pemerintah tersebut.

Pasal 2 ayat 2 Peraturan Menteri Agraria dan Tata Ruang/Kepala Badan Pertanahan Nasional Nomor 6 Tahun 2018 tentang Pendaftaran Tanah Sistematis Lengkap berbunyi "Peraturan Menteri ini bertujuan untuk mewujudkan pemberian kepastian hukum dan perlindungan hukum Hak atas Tanah masyarakat berlandaskan asas sederhana, cepat, lancar, aman, adil, merata dan terbuka serta akuntabel, sehingga dapat meningkatkan kesejahteraan dan kemakmuran masyarakat dan ekonomi negara, serta mengurangi dan mencegah sengketa dan konflik pertanahan"

Berdasarkan Penelusuran Peraturan Pemerintah Nomor 24 Tahun 1997 Tentang Pendaftaran Tanah dan Peraturan Menteri Agraria dan Tata Ruang Nomor 6 Tahun 2018 tentang Pendaftaran Tanah Sistematis Lengkap, asas sederhana memiliki definisi yang sama, karena dalam hal ini tujuan Pendaftaran Tanah Sistematis Lengkap merupakan implementasi dari asas-asas pendaftaran tanah dalam Pasal 2 Peraturan Pemerintah Nomor 24 Tahun 1997 yang berupa asas sederhana, aman, mutakhir dan terbuka, sehingga tidak ada perbedaan dalam Peraturan Pemerintah Nomor 24 Tahun 1997 Tentang Pendaftaran Tanah dan Peraturan Menteri Agraria dan Tata Ruang/Kepala Badan Pertanahan Nasional Nomor 6 Tahun 2018 tentang Pendaftaran Tanah Sistematis Lengkap mengenai asas sederhana, yang diartikan sebagai asas yang mengatur agar ketentuan-ketentuan pokok dalam pendaftaran tanah maupun prosedurnya tidak berbelit-belit, dan mudah dipahami oleh pihakpihak yang berkepentingan, terutama para pemegang hak atas tanah. Prosedur pengumpulan data penguasaan tanah dipertegas, dipersingkat dan disederhanakan, sehingga adanya kepastian hukum serta kemudahan terhadap kepemilikan tanah yang merupakan tujuan pendaftaran tanah.

Mekanisme yang dilakukan oleh pemohon Pendaftaran Tanah Sistematis Lengkap adalah meliputi tahapan penyuluhan, pendataan, pembuktian hak, pengumuman dan pengesahan serta penerbitan sertipikat. Mekanisme pertama yaitu penyuluhan, penyuluhan dilaksanakan di wilayah desa/kelurahan oleh petugas penyuluh dari Badan Pertanahan Nasional. Diikuti oleh seluruh peserta Pendaftaran Tanah Sistematis Lengkap. Penyuluhan ini harus ditekankan untuk membangun pemahaman masyarakat terhadap prosedur-prosedur yang menggunakan bahasa hukum yang mungkin sulit di pahami oleh masyarakat seperti menjelaskan bukti setor Bea Perolehan Hak atas Tanah dan Bangunan (BPHTB) serta pajak penghasilan $(\mathrm{PPh})$, menjelaskan biaya-biaya yang tidak ditanggung Anggaran Pendapatan Belanja Negara (APBN) dalam Keputusan Menteri Nomor 25/SKB/V/2017, dan sebagainya.

Kedua adalah pendataan, pengumpulan data fisik (pengukuran dan pemetaan bidang tanah) dilakukan oleh satuan tugas fisik. Pengumpulan data yuridis yang meliputi pengumpulan alat bukti kepemilikan atau penguasaan tanah yang dilakukan satuan tugas yuridis. Dalam tahap ini, petugas akan menanyakan riwayat kepemilikan tanah (apakah merupakan hibah, warisan, atau jual-beli), dan riwayat pajak. Ketiga adalah pembuktian hak, dalam melakukan pembuktian hak, perlu dilakukan pengukuran data fisik penelitian penelitian data yuridis. Saat dilakukan pengukuran data fisik, pemohon harus hadir untuk dapat menunjukkan letak, 
bentuk bidang, luas tanah, serta batas bidang tanah. Selain itu, pengukuran lahan juga memerlukan persetujuan dari pemilik tanah yang berbatasan.

Keempat adalah pengumuman dan pengesahan, selama 14 hari, pengumuman persetujuan pengajuan sertipikat tanah akan ditempel di kantor kelurahan, atau kantor pertanahan. Pemohon berkesempatan untuk mengajukan keberatan mengenai isi pengumuman tersebut. Kelima adalah penerbitan sertipikat, sertipikat dibagikan oleh petugas Badan Pertanahan Nasional dan diserahkan langsung kepada pemohon. Waktu total yang dibutuhkan untuk pemohon sertipikat dari mulai menyerahkan dokumen dan verifikasi sekitar 45 hari.

Persyaratan dan mekanisme tersebut menunjukkan bahwa prosedur pendaftaran tanah dan syarat-syarat yang harus dipenuhi telah sesuai dengan peraturan perundang-undangan tentang pendaftaran tanah dan dari alur serta penjelasan yang dibuat mudah dipahami, jelas, dan singkat sehingga telah memenuhi unsur-unsur dalam asas sederhana yang terdapat dalam Peraturan Pemerintah Nomor 24 Tahun 1997 tentang Pendaftaran Tanah dan Peraturan Menteri Agraria dan Tata Ruang/Kepala Badan Pertanahan Nasional Nomor 6 Tahun 2018 Tentang Pendaftaran Tanah Sistematis Lengkap yang diartikan sebagai asas yang mengatur agar ketentuan-ketentuan pokok dalam pendaftaran tanah maupun prosedurnya tidak berbelit-belit, dan mudah dipahami oleh pihak-pihak yang berkepentingan, terutama para pemegang hak atas tanah. Prosedur pengumpulan data penguasaan tanah dipertegas, dipersingkat dan disederhanakan, sehingga adanya kepastian hukum serta kemudahan terhadap kepemilikan tanah yang merupakan tujuan pendaftaran tanah.

\section{B. Implementasi Asas Sederhana Program Pendaftaran Tanah Sistematis Lengkap dalam menjamin Hak Keperdataan.}

Secara keseluruhan, untuk mengetahui implementasi asas sederhana program Pendaftaran Tanah Sistematis Lengkap terhadap masyarakat di Kota Samarinda, dilakukan dengan kuesioner 5 pertanyaan. Pengkategorian tanggapan responden diketahui dari jawaban responden yang merupakan 10 masyarakat di Kelurahan Rapak Dalam Kecamatan Loa Janan Ilir, 10 masyarakat di Kelurahan Gunung Lingai Kecamatan Sungai Pinang, 10 masyarakat di Kelurahan Sempaja Barat Kecamatan Samarinda Utara dan 10 masyarakat di Kelurahan Pelita Kecamatan Samarinda Ilir yang membuat sertipikat tanah, kemudian mengkaji apakah pelaksanaan program Pendaftaran Tanah Sistematis Lengkap telah memenuhi empat unsur dalam asas sederhana pendaftaran tanah. 
Diagram 1.2 Hasil kuesioner tingkat pemahaman terhadap peraturan perundang-undangan

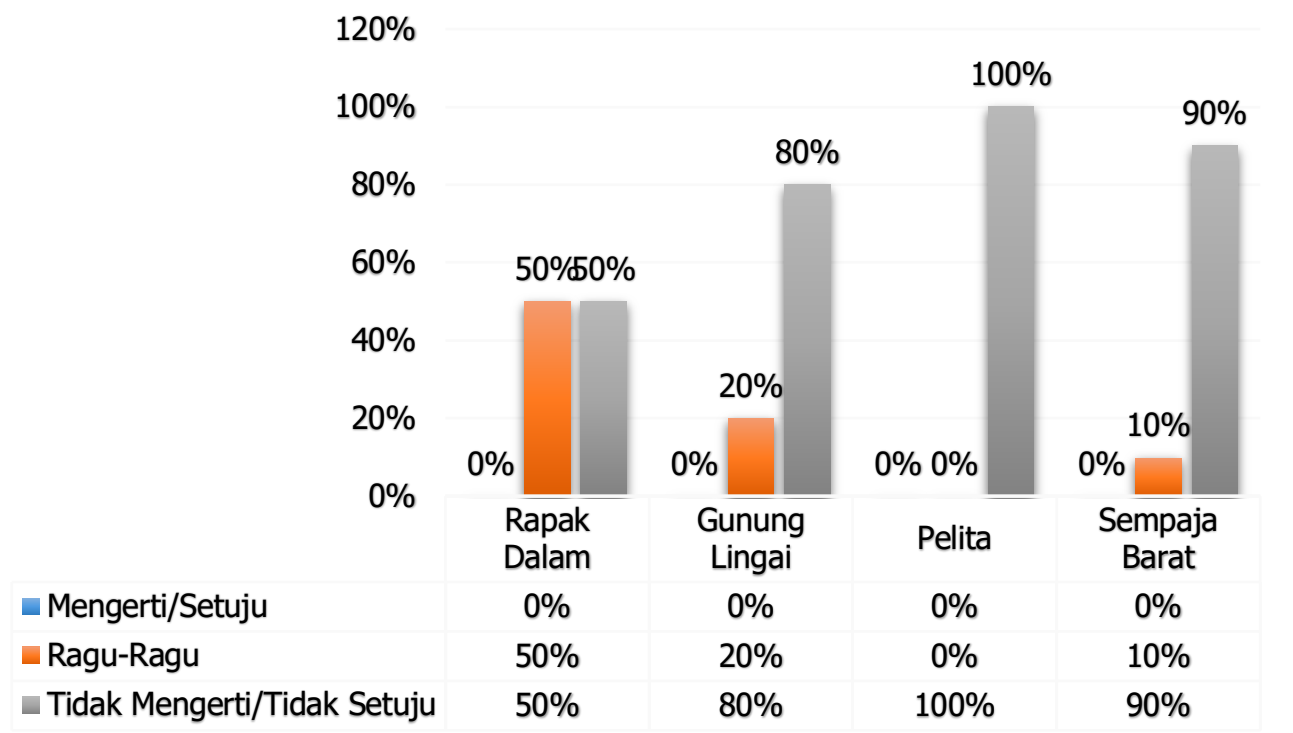

Sumber: Hasil olah data dari penelitian lapangan di Kelurahan Rapak Dalam, Gunung Lingai, Pelita dan Sempaja Barat.

Dalam tingkat pemahaman terhadap peraturan perundang-undangan, Kelurahan Pelita merupakan kelurahan yang paling kurang pemahamannya yaitu 10 dari 10 responden tidak mengerti terhadap peraturan perundang-undangan.

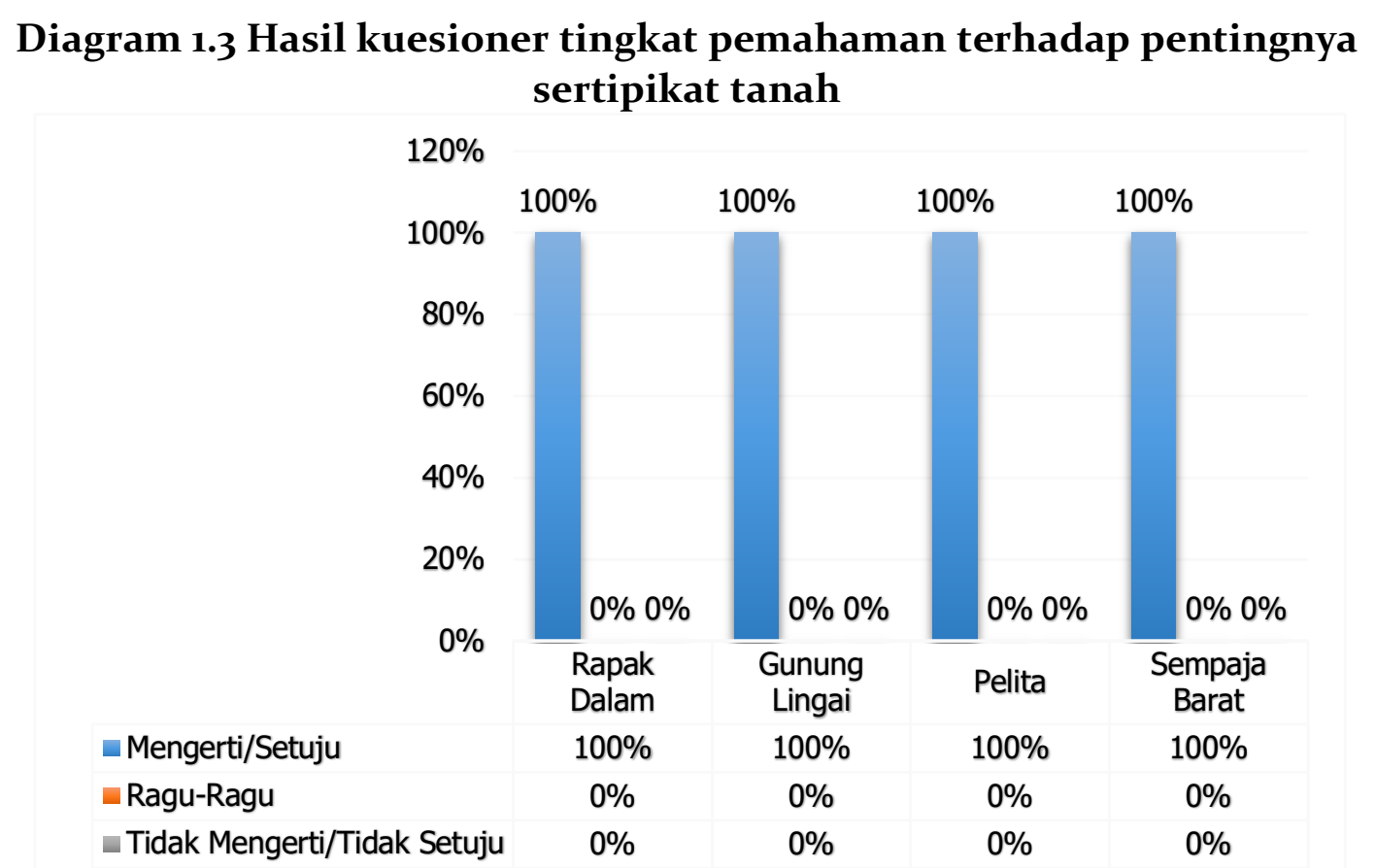

Sumber: Hasil olah data dari penelitian lapangan di Kelurahan Rapak Dalam, Gunung Lingai, Pelita dan Sempaja Barat.

Dalam pemahaman terhadap pentingnya sertipikat tanah, seluruh responden Kelurahan yaitu Kelurahan Rapak Dalam, Kelurahan Gunung Lingai, Kelurahan Pelita dan Kelurahan Sempaja barat mengerti bahwa pentingnya sertipikat bagi kepemilikan tanah. 


\section{Diagram 1.4 Hasil kuesioner tingkat pemahaman responden terhadap petunjuk dan mekanisme pendaftaran tanah}

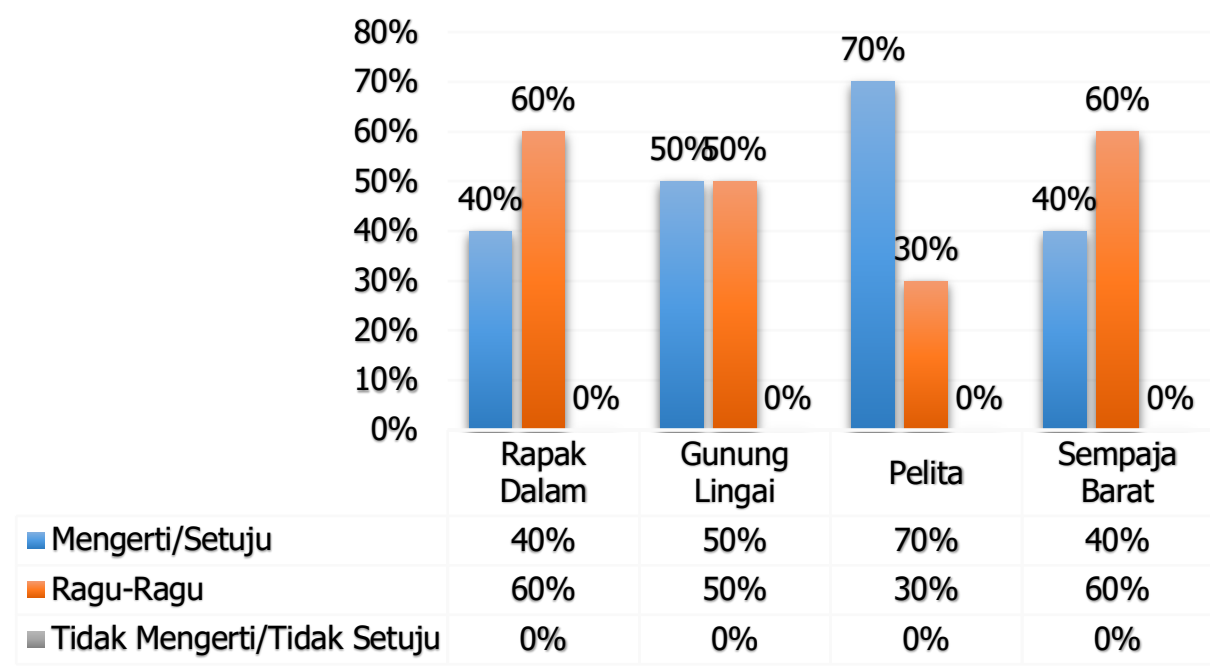

Sumber: Hasil olah data dari penelitian lapangan di Kelurahan Rapak Dalam, Gunung Lingai, Pelita dan Sempaja Barat.

Dalam tingkat pemahaman responden terhadap petunjuk dan mekanisme pendaftaran tanah, Kelurahan Gunung Lingai merupakan Kelurahan yang paling kurang pemahamannya yaitu 5 dari 10 responden tidak mengerti terhadap petunjuk dan mekanisme pendaftaran tanah.

\section{Diagram 1.5 Hasil kuesioner tingkat pemahaman terhadap asas sederhana} dalam pendaftaran tanah

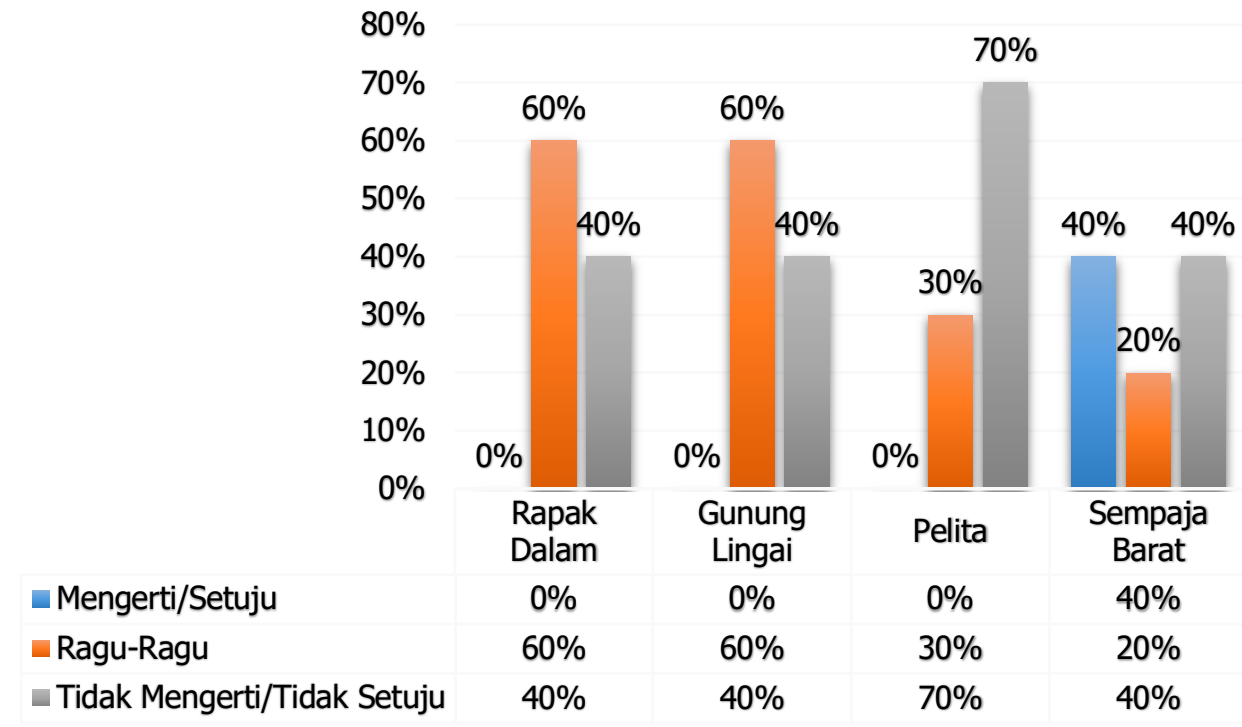

Sumber: Hasil olah data dari penelitian lapangan di Kelurahan Rapak Dalam, Gunung Lingai, Pelita dan Sempaja Barat.

Dalam pemahaman terhadap asas sederhana dalam pendaftaran tanah, Kelurahan Pelita merupakan kelurahan yang paling kurang pemahamannya yaitu 7 dari 10 responden tidak mengerti asas sederhana dalam pendaftaran tanah. 


\section{Diagram 1.6 Hasil kuesioner terhadap hambatan dalam mengurus sertipikat}

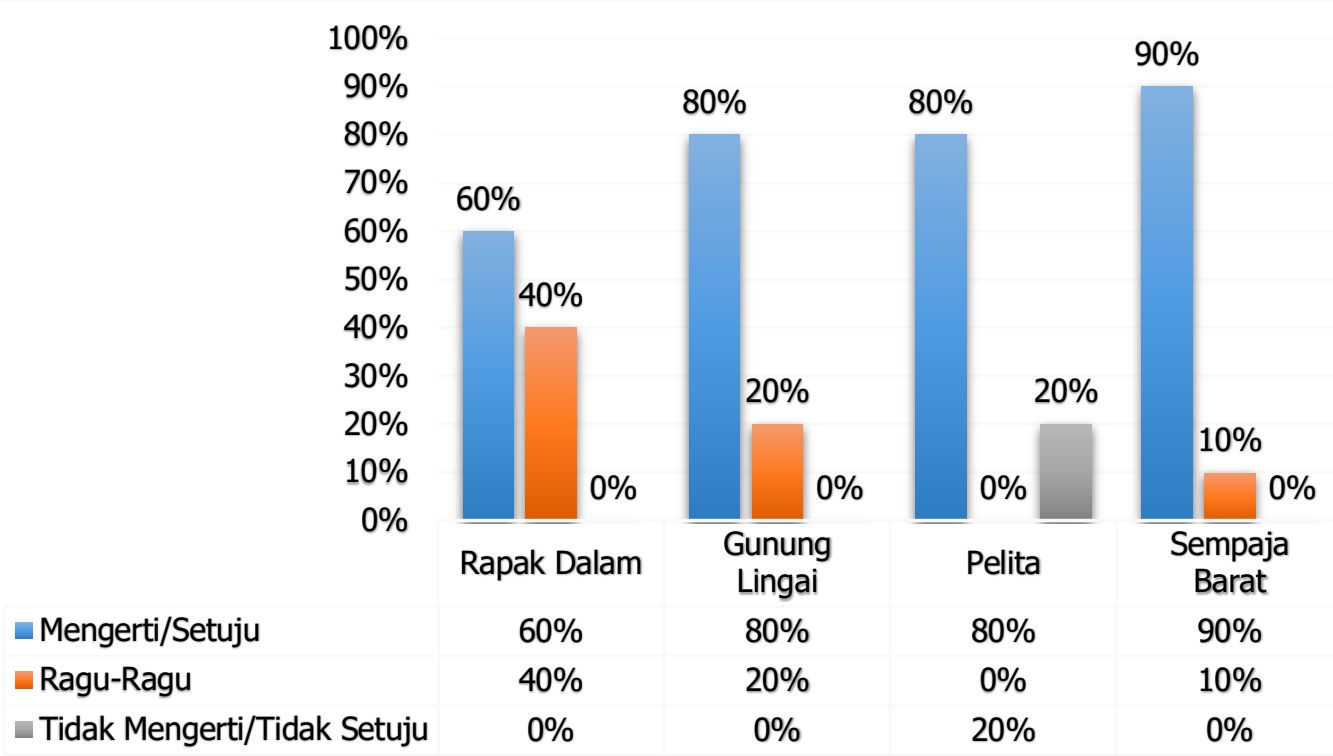

Sumber: Hasil olah data dari penelitian lapangan di Kelurahan Rapak Dalam, Gunung Lingai, Pelita dan Sempaja Barat.

Dalam hambatan dalam mengurus sertipikat, Kelurahan Sempaja Barat merupakan Kelurahan yang paling banyak mengalami hambatan dalam mengurus sertipikat tanah.

Dari wawancara penulis dengan Mochamad Ikhsan Ketua Ajudikasi Pendaftaran Tanah Sistemati Lengkap Kota Samarinda, yang menjadi kendala utama dalam pelaksanaan Pendaftaran Tanah Sistematis Lengkap adalah partisipasi masyarakat yang kurang koorperatif dalam melengkapi berkas administrasi dan syarat-syarat lain untuk membuat sertipikat tanah, walaupun sumber daya manusia telah dikerahkan dan teknologi yang memudahkan pengukuran, namun warga tidak mau memasang patok batas pada tanah mereka, padahal juru ukur tidak dapat mengukur jika tidak ada patok batas. Masyarakat masih bingung dengan patok batas sehigga tanah mereka belum memenuhi syarat untuk dikeluarkan sertipikat. Bidang tanah terdiri atas 4 (empat) kluster yaitu :

a. Kluster 1 (K1) adalah bidang tanah yang data fisik dan data yuridisnya memenuhi syarat untuk diterbitkan sertipikat hak atas tanah (eviden Sertipikat).

b. Kluster (K2) adalah bidang tanah yang data fisik dan data yuridisnya memenuhi syarat untuk diterbitkan sertipikat hak atas tanah namun terdapat perkara di Kluster (K3) adalah bidang tanah yang data fisik dan/atau data yuridisnya tidak dapat dibukukan dan diterbitkan sertipikat hak atas tanah, karena subyek dan/atau obyek haknya belum memenuhi persyaratan tertentu yang ditetapkan dalam Peraturan Menteri Agraria dan Tata Ruang/Kepala Badan Pertanahan Nasional Nomor 6 Tahun 2018 tentang Pendaftaran Tanah Sistematis Lengkap.

c. Kluster (K4) adalah bidang tanah yang obyek dan subyeknya sudah terdaftar dan sudah bersertipikat hak atas tanah, baik yang belum maupun yang sudah dipetakan namun tidak sesuai dengan kondisi lapangan atau terdapat perubahan data fisik, maka wajib dilakukan pemetaannya ke dalam Peta PTSL dengan hasil kegiatan berupa Peta Bidang Tanah yang sudah ditingkatkan 
kualitasnya sesuai dengan Peraturan Menteri Agraria Dan Tata Ruang/Kepala Badan Pertanahan Nasional Nomor 3 Tahun 2016 Tentang Pendaftaran Tanah Sistematis Lengkap.

Hanya bidang tanah kategori Kluster 1 (satu) yang dapat dikeluarkan sertipikat, bidang tanah masyarakat rata-rata berada di kategori kluster 3 (tiga) karena tidak lengkapnya syarat syarat.

Selain itu kendala lainnya adalah protesnya masyarakat terhadap hasil pengukuran data fisik yang berbeda dengan data yuridis milik pendaftar. Padahal hal itu dapat terjadi karena banyak faktor, salah satunya alat ukur bidang tanah yang sudah canggih. Berbeda dengan dulu, setelah diukur dibawa ke kantor dan kemudian diolah datanya agar dapat bidang tanahnya, sekarang alat ukur menggunakan teknologi Global Posiotioning System Real Time Kinematics (GPS RTK) yang jika diukur maka akan langsung mendapatkan posisi koordinatnya. Faktor lain yang dapat mempengaruhi ukuran bidang tanah adalah erosi atau pergeseran tanah (Ikhsan, 2019).

Dari hasil kuesioner dengan responden dan wawancara terhadap Ketua Ajudikasi Pendaftaran Tanah Sistematis Lengkap di Kota Samarinda menunjukkan bahwa bahasa hukum dan bahasa teknis dalam prosedur pendaftaran tanah seringkali sulit dipahami oleh masyarakat dalam membuat sertipikat tanah yang mengakibatkan prosedur pendaftaran tanah tidak seperti yang ada dibayangan masyarakat, meskipun beberapa kelurahan telah dua kali menjadi lokasi kegiatan Pendaftaran Tanah Sistematis Lengkap, namun tetap saja pemahaman masyarakatnya cenderung kurang baik dan itu merupakan hal yang wajar. Terkait pendaftaran tanah diperlukan prinsip kehati-hatian sehingga prosedur tersebut memang harus dilalui untuk menjamin kebenaran data tentang tanah dan kepemilikan tanah.

Hak keperdataan adalah hak yang berada di lapangan hukum perdata. Hak keperdataan terbagi menjadi dua yaitu hak mutlak dan hak relatif.

1. Hak Mutlak

Hak mutlak adalah hak yang memberikan wewenang atau kekuasaan kepada setiap orang untuk melakukan suatu perbuatan yang harus dihormati oleh orang lain. Hak mutlak terdiri dari:

a. Hak kepribadian, adalah hak yang melekat pada pribadi seseorang, misalnya hak untuk hidup atau hak atas namanya.

b. Hak-hak yang terletak danlam hukum keluarga, adalah hak yang timbul karena adanya hubungan dalam keluarga misalnya suami istri atau orang tua dan anak.

c. Hak atas suatu benda, atau disebut hak kebendaan

2. Hak Relatif

Hak relatif adalah semua hak yang timbul karena adanya hubungan perutangan, adanya hak relatif memberikan wewenang kepada seseorang untuk menuntut orang lain untuk berbuat, tidak berbuat atau memberikan sesuatu (Aini et al., 2014).

Hak atas kepemilikan atas tanah yang dibuktikan dengan sertipikat merupakan bagian dari hak keperdataan secara mutlak. Hak yang berupa hak atas suatu benda atau disebut hak kebendaan. Salah satu unsur hak keperdataan adalah hak 
kebendaan yakni hak untuk memiliki benda, Hukum benda adalah hukum yang mengatur hubungan subjek hukum dengan benda yang menimbulkan hak kebendaan. Hak keperdataan masyarakat atas suatu benda yang mereka miliki tentulah harus diberikan jaminan hukum. Benda atau zaak adalah segala sesuatu yang dapat menjadi objek hak milik (Kitab Undang-Undang Hukum Pidana). Objek hak milik dapat berupa barang dan dapat pula berupa hak.

Hak masyarakat dalam hak kebendaan merupakan hak untuk menguasai benda secara langsung dan kekuasaan tersebut dapat dipertahankan setiap orang (Kitab Undang-Undang Hukum Pidana). Hak-hak atas tanah yang tertuang dalam Peraturan Dasar Pokok-Pokok Agraria, merupakan hak keperdataan tiap-tiap warga negara Indonesia, baik laki-laki maupun wanita mempunyai kesempatan yang sama untuk memperoleh sesuatu hak atas tanah serta untuk mendapat manfaat dan hasilnya, baik dari diri sendiri maupun keluarganya.

Apabila dalam membuat sertipikat tanah belum memenuhi asas sederhana, maka akan berimplikasi terhadap hak keperdataan pemegang atas tanah karena terhambatnya proses membuat sertipikat tanah dilihat dari sebagian besar responden yang penulis wawancarai memiliki hambatan dalam menjalani prosedur yang mengakibatkan terhambatnya masyarakat untuk mendapatkan hak keperdataan pemegang hak atas tanah yaitu sertipikat tanah.

\section{KESIMPULAN}

Asas sederhana dalam Peraturan Pemerintah Nomor 24 Tahun 1997 Tentang Pendaftaran Tanah dan Peraturan Menteri Agraria dan Tata Ruang Nomor 6 Tahun 2018 tentang Pendaftaran Tanah Sistematis Lengkap memiliki definisi yang sama, yaitu asas yang mengatur agar ketentuan-ketentuan pokok dalam pendaftaran tanah maupun prosedurnya tidak berbelit-belit, dan mudah dipahami oleh pihak-pihak yang berkepentingan, terutama para pemegang hak atas tanah. Prosedur pengumpulan data penguasaan tanah dipertegas, dipersingkat dan disederhanakan, sehingga adanya kepastian hukum serta kemudahan terhadap kepemilikan tanah yang merupakan tujuan pendaftaran tanah. Implementasi asas sederhana di lokasi penelitian penulis belum berjalan secara optimal karena bahasa hukum dan bahasa teknis dalam prosedur pendaftaran tanah seringkali sulit dipahami oleh masyarakat yang mengakibatkan prosedur pendaftaran tanah tidak seperti yang ada dibayangan masyarakat yang mengakibatkan terhambatnya masyarakat untuk mendapatkan hak keperdataan pemegang hak atas tanah yaitu sertipikat tanah, yang berimplikasi belum terciptanya asas sederhana dalam Pendaftaran Tanah Sistematis Lengkap.

\section{SARAN}

Asas sederhana dalam peraturan perlu dikonkretkan regulasi teknisnya untuk menafsirkan asas sederhana tersebut agar tidak terjadi lagi hambatan dalam prosedur pendaftaran tanah sehingga menjamin kepastian hukum serta kemudahan dalam pendaftaran tanah yang merupakan tujuan pendaftaran tanah. Kepada pihak penyelenggara Pendaftaran Tanah Sistematis Lengkap yakni Badan Pertanahan Nasional dibantu oleh tim ajudikasi Pendaftaran Tanah Sistematis Lengkap untuk secara berkala melakukan penyuluhan dengan memberikan informasi dan mebangun komunikasi 


\section{UCAPAN TERIMA KASIH}

Penulis mengucapkan terima kasih kepada pihak Fakultas Hukum Universitas Mulawarman yang telah membantu penulis untuk menyelesaikan penelitian ini.

\section{DAFTAR PUSTAKA}

\section{Buku/Jurnal/Makalah :}

Aini, L. N., Runtung, Syahrin, A., \& Sembiring, R. (2014). Perlindungan Hukum Hak Keperdataan Warga Masyarakat Di Atas Tanah Yang Berada Dalam Kawasan Hutan Berdasarkan Sk Menteri Kehutanan Ri No. Sk. 463/Menhut-Ii/2013 Di Kota Batam. USU Law Journal, 2(3), 99-114.

Ikhsan, M. (2019). Wawancara Pra Penelitian.

Marzuki, M., \& Peter. (2006). Penelitian Hukum (Cetakan ke). Kencana Prenada Media Group.

Mujiburohman, D. A. (2018). Potensi Permasalahan Pendaftaran Tanah Sistematik Lengkap (PTSL). BHUMI: Jurnal Agraria Dan Pertanahan, 4(1), 88-101. https://doi.org/10.31292/jb.v4i1.217

Sembiring Joses, J. (2010). Panduan Mengurus Sertifikat Tanah. visimedia.

Sumardjono, M. S. (2005). Kebijakan Pertanahan Antara Regulasi dan Implementasi. KOMPAS, 34 .

Wahyono, E. B. (2017). Implementasi Regulasi Tentang Surveyor Kadaster Berlisensi Badan Pertanahan Provinsi Sumatera Utara. BHUMI: Jurnal Agraria Dan Pertanahan, 3(2), 217-231.

Waluyo, B. (2002). Penelitian Hukum Dalam Praktek. Sinar Grafika.

\section{Peraturan Perundang-Undang :}

Indonesia, R. (1945). Undang-Undang Dasar Negara Republik Indonesia

Indonesia, R. (1946). Kitab Undang-Undang Hukum Pidana.

Indonesia, R. (2016). Peraturan Menteri Agraria dan Tata Ruang/Kepala Badan Pertanahan Nasional Nomor 3 Tahun 2016 Tentang Pendaftaran Tanah Sistematis Lengkap.

Indonesia, R. (2018). Peraturan Menteri Agraria dan Tata Ruang/Kepala Badan Pertanahan Nasional Nomor 6 Tahun 2018 tentang Pendaftaran Tanah Sistematis Lengkap.

Indonesia, R. (1997). Peraturan Pemerintah Republik Indonesia Nomor 24 Tahun 1997 tentang Pendaftaran Tanah. 